\title{
Effect of Using Urea Formaldehyde Modified with Extracts in Plywood on Formaldehyde Emission
}

\section{Učinak upotrebe urea-formaldehida modificiranog ekstraktima na emisiju formaldehida furnirske ploče}

\author{
Original scientific paper • Izvorni znanstveni rad \\ Received-prispjelo: 5. 2. 2020. \\ Accepted-prihvaćeno: 26. 5. 2021. \\ UDK: $630 * 824.328 ; 630 * 832.282 .7 ; 630 * 892.47$ \\ https://doi.org/10.5552/drvind.2021.2005
}

\begin{abstract}
Formaldehyde-based adhesives are used in the forestry industry. This is because formaldehyde is inexpensive, easy to use and resistant to moisture; it also has particular mechanical effects. Formaldehyde has both advantages and disadvantages. It is known that various diseases such as lung cancer occur in humans as a result of the release of formaldehyde into the air during and after board production. In this study, a urea formaldehyde glue mixture was prepared by using four different fillers (extract of maritime pine (Pinus pinaster) and elm (Ulmus glabra) bark, extract of hazelnut (Corylus avellana) husk and acorn tannins) at two different ratios. The bonding shear strength of pine (Pinus sylvestris) and spruce (Picea orientalis) plywood produced with urea formaldehyde adhesive was tested according to EN 314-1 standard. All plywood, except the plywood with acorn tannin, met the requirements of the standard. A formaldehyde emission test of the plywood was carried out in accordance with EN 713-3 standard. With this approach, it is possible to quickly determine formaldehyde emissions. Experimental results were obtained for subsequent measurements, including chamber tests. It was observed that the elm bark extract reduced the formaldehyde emission of pine plywood by $40 \%$, while other fillers reduced it by 3-37\%.
\end{abstract}

Keywords: formaldehyde emission; plywood; elm bark; hazelnut husk; tannin; urea formaldehyde

SAŽETAK • U drvoprerađivačkoj industriji upotrebljavaju se ljepila na bazi formaldehida zato što je taj aldehid jeftin, jednostavan za uporabu, otporan na vlagu i ima posebne mehaničke učinke. Formaldehid ima određenih prednosti i nedostataka. Poznato je da se u ljudi koji rade u drvoprerađivačkoj industriji pojavljuju različite bolesti poput raka pluća, što može biti posljedica ispuštanja formaldehida u zrak tijekom i nakon proizvodnje ploča. Za ovo je istraživanje pripremljena smjesa urea-formaldehidnog ljepila dodavanjem četiriju različitih punila: ekstrakta kore primorskog bora (Pinus pinaster) i brijesta (Ulmus glabra), ekstrakta ljuske lješnjaka (Corylus avellana) i tanina žira u dva različita omjera. Posmična čvrstoća furnirske ploče od borovine (Pinus sylvestris) i smrekovine (Picea orientalis), proizvedene uporabom urea-formaldehidnog ljepila, ispitana je prema normi EN 314-1. Sve furnirske ploče, osim onih s taninom iz žira, zadovoljile su zahtjeve norme. Ispitivanje emisije formaldehida iz furnirskih ploča provedeno je prema normi EN 713-3. Tim je pristupom moguće brzo odrediti emisije formaldehida. Dobiveni su eksperimentalni rezultati za naknadna mjerenja, uključujući ispitivanje u komori. Primijećeno je da je ekstrakt kore brijesta smanjio emisiju formaldehida furnirske ploče od borovine za $40 \%$, dok su ostala punila smanjila tu emisiju za $3-37 \%$.

Ključne riječi: emisija formaldehida; furnirska ploča; kora drva brijesta; ljuska lješnjaka; hrapavost površine

\footnotetext{
Authors are research assistant and professor at Karadeniz Technical University, Faculty of Forestry, Department of Forest Industry Engineering, Trabzon, Turkey.
} 


\section{INTRODUCTION}

\section{UVOD}

The increasing demand for wood products and the decrease in the presence and quality of wood raw materials have gradually increased the importance of composite wood products. Wood-based composite panels such as plywood, particleboard and fibreboard are among the most widely used materials in the whole world (Aydin et al., 2010). These materials are used widely for construction, decoration and furnishing of homes, offices, schools, as well as other non-industrial workplaces, and many of these materials have high formaldehyde emissions (FE) due to the use of such things as solvent-borne paints and adhesives (Böhm et al., 2012).

Most adhesives used in plywood production are urea formaldehyde (UF), phenol formaldehyde (PF) and melamine formaldehyde (MF) adhesives (Ružiak et al., 2017). The use of urea-formaldehyde adhesive, as the main adhesive used by the forest industry, is due to its excellent adhesion to lignocellulosic materials, excellent intrinsic cohesion, ease of handling and application, lack of colour in the finished product and low cost. However, lack of resistance to weather and water and its susceptibility to emission of formaldehyde vapours are two main disadvantages of UF adhesive (Aydin et al., 2006).

Formaldehyde is produced by oxidizing methane or methanol in the presence of a catalyst. $70 \%$ of this production is only used in the synthesis of formaldehyde-based adhesives (Stefanowski, 2018). This is because their prices are low, they do not absorb moisture, are resistant to mechanical effects and are easy to use (Çolak, 2002). Additionally, FE is elevated, even in the absence of adhesives in wood. Certain reports have mentioned that FE is produced from wood during hotpressing of composite panels, and it is generally accepted that FE from the wood is an insignificant contributor to the total measurable level of $\mathrm{FE}$ in a composite wood product (Böhm et al., 2012).

A variety of test methods have been developed for determining the initial emittable formaldehyde concentrations from wood-based products. Each method has its own special set of board conditioning and test conditions that have both positive and negative attributes. Large chamber tests, such as the European large chamber test, are expensive, time-consuming and need a large quantity of the sample. Consequently, it is impractical to use this technique for quality assurance in commercial production. Other methods, such as gas analysis, using a perforator or a desiccator, are widely used in quality production control for factories and save time in comparison to the referenced methods (chambers), which need 7-28 days (Böhm and Salem, 2012). Regarding equipment cost, analysis time and informative value in combination, the most promising method for rapid formaldehyde emission analysis is the flask method. This method has been used consistently for formaldehyde emission, not at least because of its experimental simplicity and good correlation with other emission test methods. The flask method may be used to quickly determine the effectiveness of formaldehyde emission reduction attempts while developing a low-emission binder system (Dorner et al., 2012).

Formaldehyde emissions cause different disturbances in humans within certain values. Irritations in eyes, nose and throat are caused at 0.1-5 ppm; tears, nasal, throat burning and breathing difficulty are caused at $10 \mathrm{ppm}$; fatal lung cancer and other serious diseases occur at $25 \mathrm{ppm}$ and above. Oral administration of a $37 \%$ aqueous solution of formaldehyde results in death (URL1, 2018). Formaldehyde is classified as a carcinogen known by the State of California, Proposition 65 (2008) and the International Health Research Agency (IARC), a division of the World Health Organization (WHO) (IARC, 2004). The National Institute of Health National Toxicology Program (NTP) states that formaldehyde is reasonably expected as a human carcinogen (Salem and Böhm, 2013a).

It is an important problem to reduce or wipe out the emission of formaldehyde in panels produced with synthetic adhesives. Formaldehyde emissions can be reduced in a number of ways, such as lowering the formaldehyde ratio during composition and addition of fillers (lignin, tannin, etc.) (Çolakoğlu, 1993).

One of the possible available materials for production of adhesive mixture fillers is the bark of domestic wood materials. Wood bark is a waste product that results out of wood raw material processing (Ružiak et al., 2017). Çöpür et al. (2007) also reported that the internal bond strength of chipboards made of hazelnut husk and urea formaldehyde adhesive meets the general-purpose particleboard standard requirement, which is the European Norm. Therefore, hazelnut husk may be used as an important filler in plywood production.

The key factors for successful utilisation of bark and hazelnut husk for adhesives are polyphenol compounds known as tannins (Ogunwusi, 2013). Formaldehyde emission from tannin-bonded panels is almost completed due to the free formaldehyde residue remaining after pressing. Flavonoid-methylene bonds (Figure 1) are resistant to any hydrolysis process due to their phenolic nature (Pizzi et al., 1994).

Tannin-based adhesives have been studied by many researchers. For example, Moubarik et al. (2013) studied a corn starch-mimosa tannin-UF adhesive mixture produced for reduction of formaldehyde emissions of the particles produced. In another study, by adding

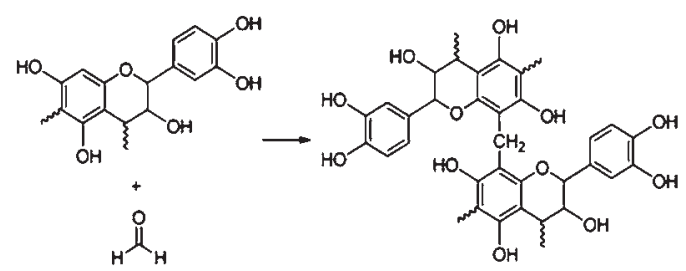

Figure 1 Reaction between tannin and formaldehyde (Arbenz and Avérous, 2015)

Slika 1. Reakcija između tanina i formaldehida (Arbenz and Avérous, 2015.) 
Table 1 Variables applied in extraction process

Tablica 1. Varijable primijenjene u postupku ekstrakcije

\begin{tabular}{|l|c|c|c|c|}
\hline Species / Vrste & $\begin{array}{c}\text { Temperature, }{ }^{\mathbf{0}} \mathbf{C} \\
\text { Temperatura, }{ }^{\circ} \mathrm{C}\end{array}$ & $\begin{array}{c}\text { Ratio }(w / v) \\
\text { Omjer }(w / v)\end{array}$ & $\begin{array}{c}\text { Time, hour } \\
\text { Vrijeme, } h\end{array}$ & $\begin{array}{c}\text { Particle moisture content, \% } \\
\text { Sadržaj vode u česticama, } \%\end{array}$ \\
\hline $\begin{array}{l}\text { Maritime pine bark } \\
\text { kora primorskog bora }\end{array}$ & 95 & $1 / 6$ & 2 & 17.18 \\
\hline Elm bark / kora brijesta & 95 & $1 / 6$ & 2 & 12.67 \\
\hline Hazelnut husk / ljuska lješnjaka & 75 & $1 / 50$ & 3 & 15.68 \\
\hline Acorn tannin / tanin žira & \multicolumn{2}{|r|}{ Supplied from a commercial company / nabavljen od komercijalne tvrtke } \\
\hline
\end{tabular}

hybrid bark extract to UF adhesive, Zhang et al. (2014) reduced plywood formaldehyde emission. Gangi et al. (2013) also added tannin to PF and MF adhesive, which produced a decrease in the formaldehyde emission of plywood. Elbadawi et al. (2015) produced particleboard by adding extracts of acacia barks as a $35 \%$ solution to 3 different proportions (5-10-15\%) of UF adhesive. There was an increase in the mechanical properties at a rate of $5 \%$. Nemli and Çolakoğlu (2005) produced particleboard by adding different amounts of mimosa bark. UF adhesive was used in particleboard production. They observed a decrease in formaldehyde emission. Aydin et al. (2017) turned walnut, fir, spruce and chestnut shells into a flour and used it as filler in plywood produced with a UF adhesive. Chestnut and fir reduced formaldehyde emission. Pirayesh et al. (2013) produced particleboard using a UF adhesive. They also used walnut and almond shells at different proportions. Formaldehyde emission and mechanical properties decreased with the increase in the walnut and almond shell ratio in the particleboard.

In this study, the effects of the use of bark extracts, hazelnut husk extracts and acorn tannin as fillers on the bonding shear strength and formaldehyde emission of plywood panels were evaluated. For this aim, besides the use of wheat flour as the control group, extract of maritime pine and elm bark, hazelnut husk extract and acorn tannins were used. Moreover, it was aimed to use wood barks and hazelnut husk as valueadded raw material for the industry.

\section{MATERIALS AND METHODS}

\section{MATERIJALI I METODE}

To be used as a filler in producing plywood, maritime pine (Pinus pinaster) bark, elm (Ulmus glabra) bark and hazelnut (Corylus avellana) husk were obtained from Trabzon in northern Turkey. Acorn tannin was purchased from a commercial company. Scots pine (Pinus sylvestris) and spruce (Picea orientalis)

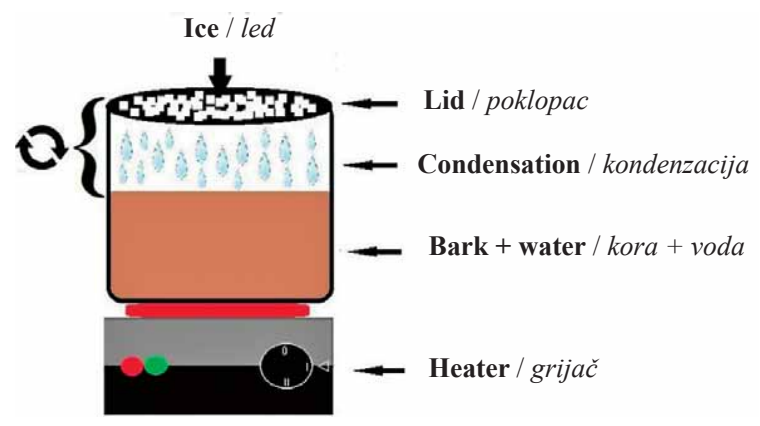

Figure 2 Hot water extraction

Figure 2. Ekstrakcija vrućom vodom

veneers used in plywood production were obtained from Karadeniz Technical University.

\subsection{Extraction process}

\subsection{Postupak ekstrakcije}

The barks and hazelnut husk peeled from wood were exposed to natural drying for 14 days. Then, a ring-type flaker was used to break the chips down to particle size before extraction. The bark and husk particles were extracted with hot water in a boiler at the solid / liquid $(w / v)$ ratios presented in Table 1.

In order to prevent the volatile compounds from escaping with the effect of heat, the extraction process as seen in Figure 2 was carried out by adding ice onto the lid during the extraction process and until the contents were cooled down in a closed boiler.

Removal of barks and husk from the solution was carried out with a 60 -mesh sieve. Then, it was boiled in a steel-bottom boiler to remove the water and increase the solid matter content. After most of the water was removed, and the density of the solution increased, it was poured into an aluminium tray and dried in an oven at $70{ }^{\circ} \mathrm{C}$ until it was completely dry. The samples taken from the oven were ground in a ring mill and turned into powder. The moisture of the extracts was measured with a Precisa brand moisture analyser. The extracts that were obtained are shown in Figure 3.

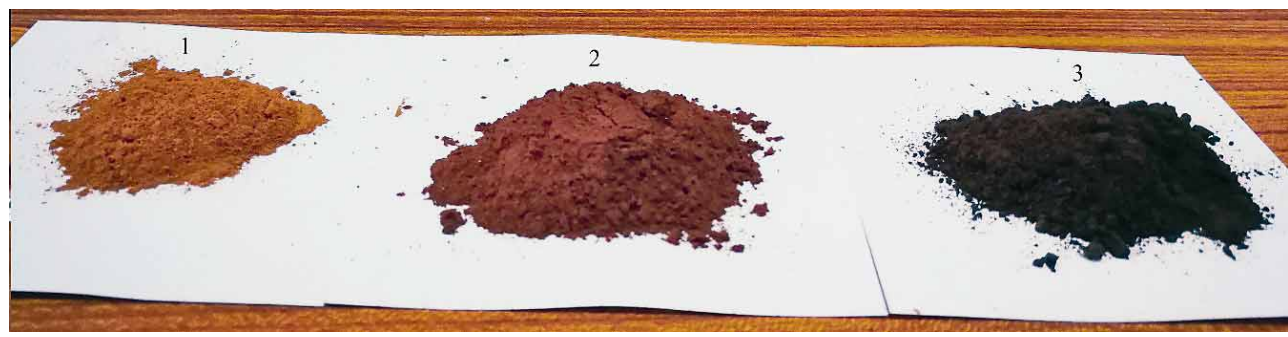

Figure 31 - Elm bark extract, 2 - Maritime pine bark extract, 3 - Hazelnut husk extract

Slika 3. 1 - ekstrakt kore brijesta, 2 - ekstrakt kore primorskog bora, 3 - ekstrakt ljuske lješnjaka 
Table 2 Glue mixture of test groups

Tablica 2. Smjesa ljepila ispitnih grupa

\begin{tabular}{|c|c|c|c|c|c|c|}
\hline \multirow{2}{*}{\multicolumn{2}{|c|}{ 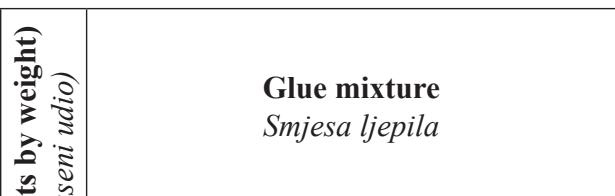 }} & \multicolumn{4}{|c|}{ Test groups / Ispitna grupa } & \multirow[b]{2}{*}{$\begin{array}{l}\mathrm{E} \\
\text { (acorn tannin } \\
\text { tanin žira) }\end{array}$} \\
\hline & & $\begin{array}{c}\text { A } \\
\text { (control / } \\
\text { kontrola) }\end{array}$ & $\begin{array}{c}\text { B } \\
\text { (maritime pine } \\
\text { bark / kora } \\
\text { primorskog bora) }\end{array}$ & $\begin{array}{c}\text { C } \\
\text { (elm bark } \\
\text { kora } \\
\text { brijesta) }\end{array}$ & $\begin{array}{c}\mathrm{D} \\
\text { (hazelnut husk } \\
\text { ljuska } \\
\text { lješnjaka) }\end{array}$ & \\
\hline$\frac{3}{3}$ & $\begin{array}{l}\text { UF adhesive (55\% solids content) } \\
\text { UF ljepilo (55\% suhe tvari) }\end{array}$ & 100 & 100 & 100 & 100 & 100 \\
\hline$=2$ & Wheat flour / filler & $30 / 0$ & $25 / 5$ & $25 / 5$ & $25 / 5$ & $25 / 5$ \\
\hline & pšenično brašno / punilo & $30 / 0$ & $27.5 / 2.5$ & $27.5 / 2.5$ & $27.5 / 2.5$ & $27.5 / 2.5$ \\
\hline & Hardener $\left(\mathrm{NH}_{4} \mathrm{Cl}\right) /$ otvrdnjivač $\left(\mathrm{NH}_{4} \mathrm{Cl}\right)$ & 10 & 10 & 10 & 10 & 10 \\
\hline
\end{tabular}

Table 3 Technical characteristics of UF adhesive Tablica 3. Tehnička svojstva UF ljepila

\begin{tabular}{|l|c|}
\hline \multicolumn{1}{|c|}{$\begin{array}{c}\text { UF adhesive characteristics } \\
\text { Svojstva UF ljepila }\end{array}$} & $\begin{array}{c}\text { UF adhesive } \\
\text { (limit value) } \\
\text { UF ljepilo } \\
\text { (granične vrijednosti) }\end{array}$ \\
\hline Solid content / suha tvar, \% & $55 \pm 1$ \\
\hline Density / gustoća, $20^{\circ} \mathrm{C}, \mathrm{g} / \mathrm{cm}^{3}$ & 1.214 \\
\hline Viscosity / viskoznost, $20^{\circ} \mathrm{C}, \mathrm{cps}$ & 140 \\
\hline $\begin{array}{l}\text { Flowing point / točka tečenja, } \\
20{ }^{\circ} \mathrm{C}, \mathrm{s}\end{array}$ & 29 \\
\hline Gel time / vrijeme želiranja, $\mathrm{s}$ & 22 \\
\hline $\mathrm{pH}, 20^{\circ} \mathrm{C}$ & 8.32 \\
\hline $\begin{array}{l}\text { Free formaldehyde / slobodni } \\
\text { formaldehid, } \%\end{array}$ & Max. 0.8 \\
\hline $\begin{array}{l}\text { Storage time / vrijeme skladištenja, } \\
20{ }^{\circ} \mathrm{C}\end{array}$ & 60 days \\
\hline
\end{tabular}

\subsection{Chemical analysis of extracts}

\subsection{Kemijska analiza ekstrakata}

The extracts for $\mathrm{pH}$ measurement of the particles were prepared according to TAPPI T m45 (1992). Five grams of the samples of each group were extracted with $150 \mathrm{ml}$ of distilled water for 24 hours. After filtering, $\mathrm{pH}$ measurements were carried out.

The Stiasny number method was used to determine the polyphenol content of the extracts. Fifty $\mathrm{ml}$ of $0.4 \% \mathrm{w} / \mathrm{w}$ tannin solution was pipetted into a $150-\mathrm{ml}$ flask. Aqueous formaldehyde $(37 \%, 5 \mathrm{ml})$ and hydrochloric acid solution $(10 \mathrm{~N}, 5 \mathrm{ml})$ were then added, and the mixture was heated under reflux for $30 \mathrm{~min}$. The reaction mixture was filtered through a sintered glass filter $(40-100 \mu \mathrm{m})$ while it was still hot. After this, the precipitate was dried in an oven at $105{ }^{\circ} \mathrm{C}$ to constant weight. The Stiasny number is the ratio of the ovendried weight of the precipitate to the total dissolved solids content of the tannin extract, expressed as a percentage (Pizzi and Mittal, 2010).

The total phenolic content of the extract samples prepared according to the Folin-Ciocalteu method is presented as gallic acid equivalent (mg GAE / $\mathrm{g}$ ).

\subsection{Preparation of glue mixture}

\subsection{Priprema smjese ljepila}

Fillers by $2.5 \%$ and $5 \%$ (by replacing wheat flour) of the UF ( $55 \%$ solid content) adhesive (Table 3 ) were added to the UF glue mixture. The glue mixture recipe used in plywood production is given in Table 2 .
The fillers obtained from the tree barks and hazelnut husk were added gradually to the UF adhesive during the preparation of the glue mixtures of all test groups, and the glue mixtures were mixed to obtain a homogenous adhesive. Finally, the hardener $\left(\mathrm{NH}_{4} \mathrm{Cl}\right)$ was added to these mixtures.

\subsection{Determination of bonding shear strength and} formaldehyde emission of plywood

2.4. Određivanje posmične čvrstoće spoja i emisije formaldehida furnirske ploče

In this study, scots pine and spruce veneers of 2 $\mathrm{mm}$ thickness and $50 \mathrm{~cm} \times 50 \mathrm{~cm}$ dimensions were dried at $110{ }^{\circ} \mathrm{C}$ to $4-6 \%$ humidity. Gluing of the veneers was carried out in a 4-roller gluing machine, and $160 \mathrm{~g} / \mathrm{m}^{2}$. The boards prepared after gluing were pressed in a single-layer hydraulic press with a pressing area of $70 \mathrm{~cm} \times 89 \mathrm{~cm}$. Pressing conditions: temperature $110{ }^{\circ} \mathrm{C}$, pressure $8 \mathrm{~kg} / \mathrm{cm}^{2}$, time 6 minutes. The produced test boards were stacked on top of each other for 1 week without using stacking slats to eliminate the difference in temperature and humidity between the inner and outer layers. Thus, form changes were prevented by ensuring the cooling of the plywood under equal conditions.

Bonding shear strength test was carried out according to EN 314-1 standard. According to this standard, the bonding shear strength test sample was prepared for 3-layer plywood (EN 314-1, 1993). The test samples prepared from plywood in each group produced with the urea formaldehyde adhesive were kept in water at $20^{\circ} \mathrm{C}$ for 24 hours, and 30 samples from each group were examined.

The formaldehyde emission values of the produced plywood were determined using the flask method in accordance with EN 717-3 (1996) standard. Two replicate tests were conducted for determination of formaldehyde emissions. The flask method is an inexpensive and simple method for testing formaldehyde release, and it is suitable for testing of uncoated boards (Aydin et al., 2017).

\subsection{Statistical analysis}

\subsection{Statistička analiza}

Simple analysis of variance was used to reveal the effects of the fillers on formaldehyde emission in addition to the bonding shear strength of plywood. The analysis of variance was carried out using the test groups common to the plywood whose effects were in- 
........ Bilgin, Colakoglu: Effect of Using Urea Formaldehyde Modified with Extracts...

Table 4 Chemical contents of extracts

Tablica 4. Kemijski sastav ekstrakta

\begin{tabular}{|l|c|c|c|c|}
\hline \multicolumn{1}{|c|}{ Species / Vrsta } & $\mathrm{pH}$ & $\begin{array}{c}\text { Total phenol } \\
\text { mg GAE/g } \\
\text { Ukupni fenoli } \\
\text { mg GAE/g }\end{array}$ & $\begin{array}{c}\text { Stiasny number*, \% } \\
\text { Stiasnyjev broj*, \% }\end{array}$ & $\begin{array}{c}\text { Extraction yield, \% } \\
\text { Stupanj ekstrakcije, \% }\end{array}$ \\
\hline Maritime pine bark / kora primorskog bora & 4.42 & $101.1238 \pm 4.0$ & 9 & 7.5 \\
\hline Elm bark / kora brijesta & 5.79 & 407.05 & 50 & 5.18 \\
\hline Hazelnut husk / ljuska lješnjaka & 6.47 & 14.04 & 31 & 13.3 \\
\hline Acorn annin / tanin žira & 3.97 & 710.3 & - & - \\
\hline
\end{tabular}

*Stiasny number of raw barks and hazelnut husk was measured. / Izmjeren je Stasnyjev broj sirove kore i ljuske lješnjaka.

vestigated. If the differences obtained by the analysis of variance were found to be significant, Student-Newman-Keuls test was used to compare the means of variance sources, and the homogeneity of the groups was determined. The SPSS 23 for Windows statistical package program was used for the statistical analyses.

\section{RESULTS AND DISCUSSION}

\section{REZULTATI I RASPRAVA}

\subsection{Chemical analysis of extracts}

\subsection{Kemijska analiza ekstrakta}

Table 4 shows the total polyphenol content, $\mathrm{pH}$ value and extraction yield of the extracted barks and husk, in addition to the Stiasny values of the raw barks and husk.

In the extraction process, the highest yield was obtained from the hazelnut husk, while the lowest yield was obtained from the elm bark. Extraction yields highly depended on the wood bark species. Usually, water extracts present more impurities than urea, carbonate and urea+sulphite extracts (Bertaud et al., 2012). Extractives obtained through hot water extraction contain hemicellulose, some acetic acid and even lignin. It is worth noting that the amount of water used during extraction has little influence on the extractive yield (Feng et al., 2013).

When the Stiasny number of the unextracted bark and husk was evaluated, the highest Stiasny number was obtained from the elm bark, and the lowest Stiasny number was obtained from the maritime pine bark. The Stiasny number gives the reactivity of our extracts to formaldehyde, and this information may help us determine if the extracts can be used as adhesives (Chupin et al., 2013). Yazaki and Collins (1994) assessed the minimum Stiasny value to produce high-quality adhesives as $65 \%$. However, Ping et al. (2011) produced good-quality adhesives while obtaining a Stiasny number of $46 \%$.

The highest total phenol content was determined in the acorn tannin, followed by the elm bark extract. The lowest total phenol content was detected in the hazelnut husk. Generally, the bark of older trees provides a higher tannin and extractive content. The outer bark of some conifers contains the greatest percentage of extractable total phenols, followed by inner bark, heartwood and sapwood. The yield of tannin from bark depends on species, age, parts of the tree and storage time after tree felling (Feng et al., 2013).

\subsection{Bonding shear strength}

3.2. Posmična čvrstoća spoja

Figure 4 shows the changes in the bonding shear strength depending on the glue mixture. The bonding shear strength of groups B and D in pine plywood was significantly higher than the control group. There was no statistically significant difference between the other groups and the control. Elbadawi et al. (2015) stated that the curing rates of formaldehyde-based adhesives were very dependent on the $\mathrm{pH}$ of the environment in which they cure. If the $\mathrm{pH}$ is low, then pre-curing may be performed. When an adhesive precures, the board's layer is weak and flaky. In a study that produced plywood using maritime pine bark extract, it was stated that the adhesion quality was shown by variables such as the polymerization degree, structure and composition of the carbohydrates and reactive polyflavonoids in the extract (Yazaki, 1994).

In spruce plywood, the bonding shear strength of groups B and E was significantly lower than the control group. There was no statistically significant difference between the other groups and the control group. It has been stated in the literature that maritime pine bark tannins can change the reaction balance according to the chemical properties of the tree species since they have a phloroglucinol A ring structure (Pizzi, 1979). Since acorn tannin has the highest polyphenol content and lowest $\mathrm{pH}$ value, it creates a thick glue line by shortening the curing time and lowering the urea / formaldehyde mole ratio as its high polyphenol content causes a negative effect on adhesion (Çolak, 2002; Nemli, 2002).

The filler ratios used in the pine and spruce plywood did not significantly affect the bonding shear strength.

Considering the difference in the bonding shear strength of the groups using fillers, as stated in the literature, the presence of pits, peaks and cracks on the surface in the microscopic examination of the veneers may be caused by the presence of irregular fibres and other defects. It is known in the literature that these surface conditions cause blockages that prevent the glue from fully wetting and lead to stresses when the glue hardens (Aydın et al., 2001). It was observed that surface defects, porous and fibrous structures were removed with the use of a filler, and it was stated in the literature that better adhesion occurs, and glue leakage is prevented (Tan and Çolakoğlu, 2010). 


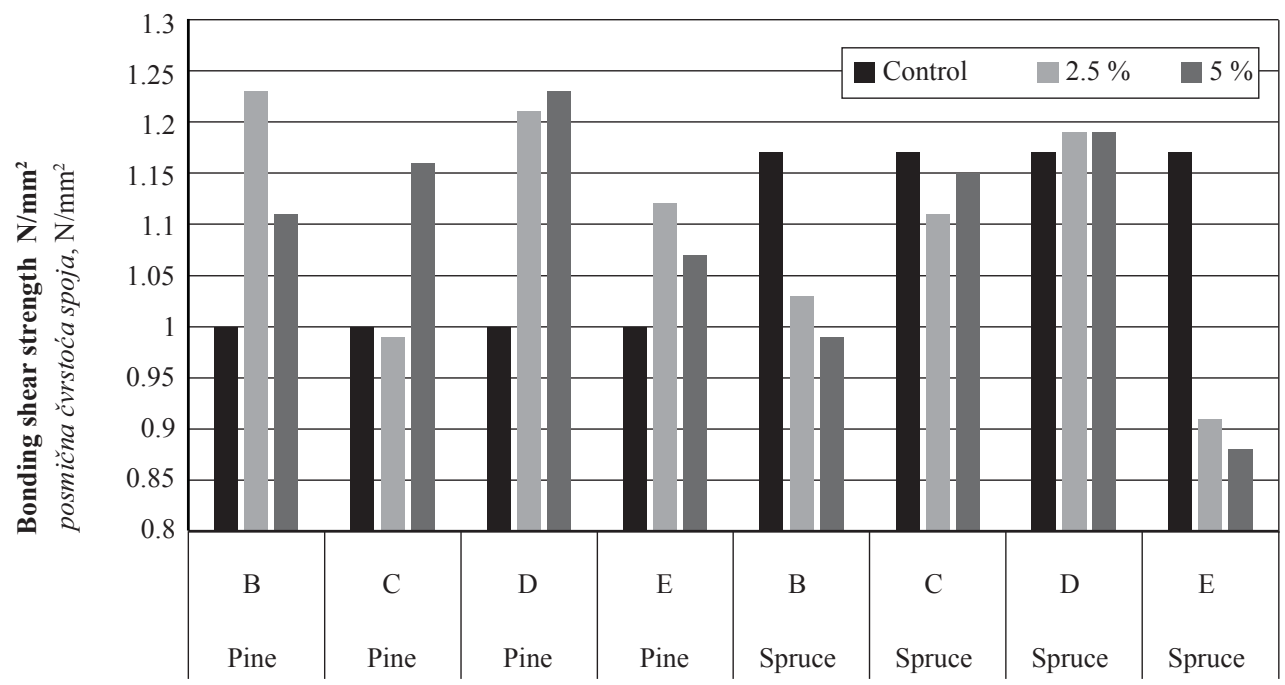

Figure 4 Bonding shear strength values

Figure 4. Vrijednosti posmične čvrstoće spoja

\subsection{Formaldehyde emission}

\subsection{Emisija formaldehida}

Formaldehyde emission for the plywood groups was determined by the flask method. The formaldehyde emission values of the test panels are given in Figure 5.

The formaldehyde emission of the filler-added groups was lower in both plywood types than the control group. The fact that fillers cause low formaldehyde emissions is due to the reaction of natural phenolic tannins with formaldehyde (Zhang et al. 2014). Aydin et al. (2017) added different bark flours to an adhesive, and the resulting plywood reduced formaldehyde emissions. Similarly, Zhang et al. (2014) added bark extract to an adhesive and observed a decrease in the formaldehyde emission of plywood.

The formaldehyde emission in pine plywood was lower than that in spruce plywood. In plywood produc-

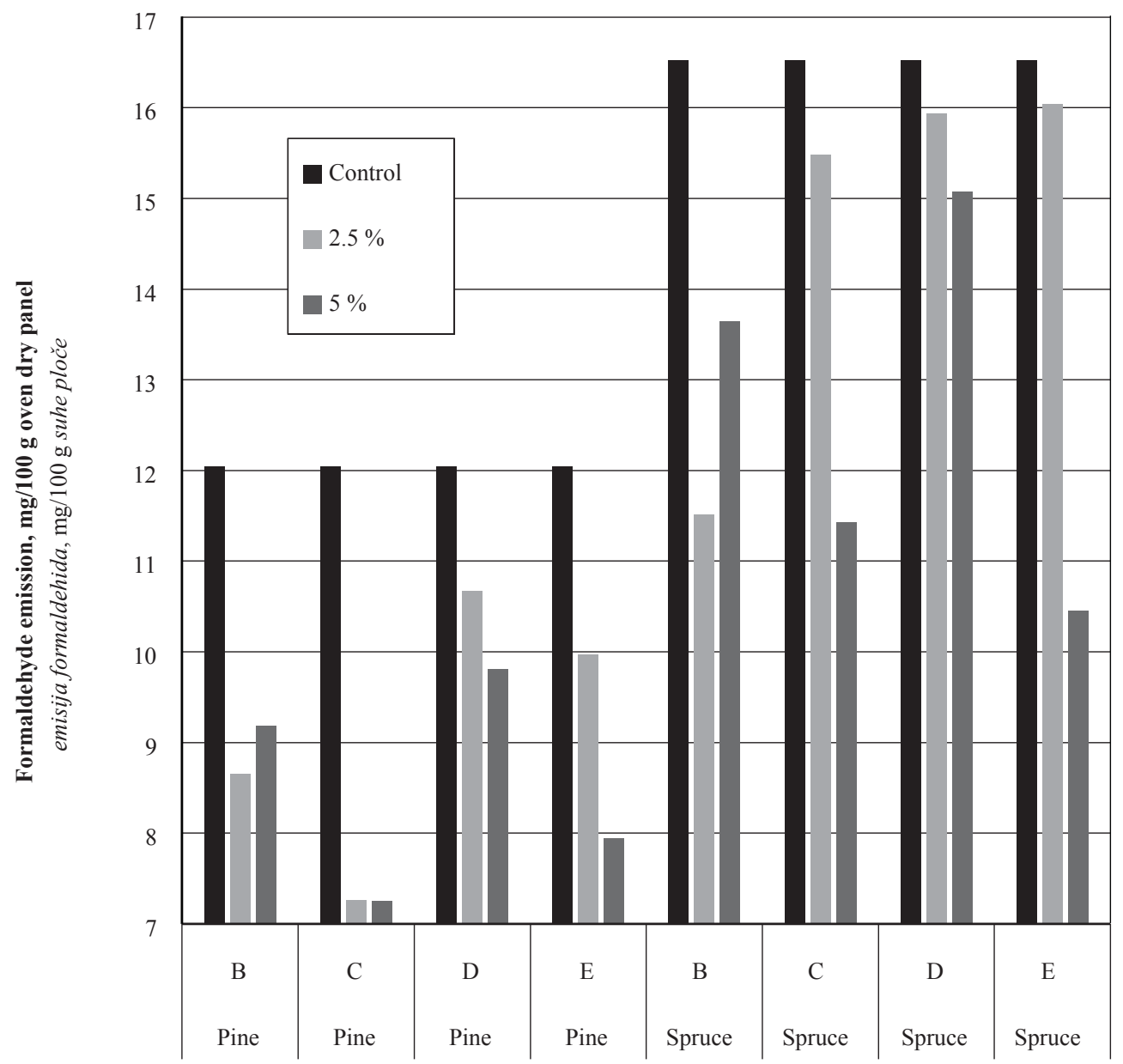

Figure 5 Formaldehyde emission values

Figure 5. Vrijednosti emisije formaldehida 
tion, the pressing temperature causes acetyl groups to be removed from the veneers to turn into acetic acid, which has a formaldehyde-binding effect. Additionally, it was found in the literature that the amount of formaldehyde decomposed from plywood surfaces depends on the anatomical structure, porosity and diffusion resistance of the tree from which the outer layer is produced (Çolakoğlu, 1993). Salem et al. (2012) stated that there are two main factors affecting the formaldehyde emission of particleboard. The first one was that the formaldehyde present in the adhesive interacted in a distinct way with each wood species and the second one that FE values were affected by the anatomy of the respective wood species. It was found in previous studies that plywood panels were manufactured with PF adhesive, and formaldehyde emission was close to that of solid wood, because the $\mathrm{C}-\mathrm{C}$ bonding in the PF adhesive was very stable against hydrolytic attacks. It is important to point out here that such low free formaldehyde values may be emitted from the wood itself, and the boards are considered formaldehyde free (Salem et al. 2013b).

In pine plywood, the lowest formaldehyde emission was determined in group C. Elm bark extract has a high polyphenol content and a high $\mathrm{pH}$ value. As a result of this, acetyl groups that are esterified with sugar units in hemicellulose in a high-temperature alkaline environment are subjected to hydrolysis, and acetyl groups have a binding effect on formaldehyde (Çolak, 2002). In groups other than the control group, the highest formaldehyde emission value was found in group D with the lowest polyphenol content. Among the fillerused groups, group B had a higher formaldehyde emission at a rate of $5 \%$ than group $\mathrm{E}$, while group $\mathrm{E}$ had a higher formaldehyde emission than group B at $2.5 \%$.

The formaldehyde emissions of spruce plywood using $5 \%$ filler were compared. In the groups other than the control group, the highest formaldehyde emission was determined in group D, and the lowest formaldehyde emission in group E. The hazelnut husk extract had the lowest quantity, and the acorn tannin extract had the highest quantity of polyphenols. Among the groups in which fillers were used, when the ratio decreased to 2.5 $\%$, the lowest formaldehyde emission was found in group B. Since maritime pine tannin has a structure of phloroglucinol ring $\mathrm{A}$, it was stated in the literature that it can change the reaction balance according to the chemical properties of the tree species (Pizzi, 1979).

In both types of plywood, it was determined that, as the filler ratio increased, the emission of formaldehyde in groups $\mathrm{C}, \mathrm{D}$ and $\mathrm{E}$ decreased. In previous studies, Nemli (2002) stated that formaldehyde emission decreased with increasing bark ratio in particleboards produced using mimosa bark.

Pirayesh et al. (2013) reported that walnut/almond shell usage rate and formaldehyde emission are inversely proportional in particleboard production. Especially the tannin content in the bark affected the formaldehyde emission.

As a result of the test performed in the group using maritime pine bark, it was observed that the increase in the filler ratio increased the formaldehyde emission.

\section{CONCLUSIONS}

\section{ZAKLJUČAK}

Maritime pine bark, elm bark and hazelnut husk were obtained from Trabzon in northern Turkey. Hot water extracts were obtained from these agricultural wastes. The acorn tannin was purchased from a commercial company. Then, the extracts and acorn tannins were added into the urea formaldehyde glue mixture at the rates of 5 $\%$ and $2.5 \%$ (replacing wheat flour) of the UF (55\% solid content) adhesive. The bonding shear strength and formaldehyde emission of the plywood produced with the modified UF adhesive were investigated.

The use of maritime pine bark extract and hazelnut husk extract in pine plywood increased the bonding shear strength significantly. In spruce plywood, the use of maritime pine bark extract and acorn tannin significantly reduced the bonding shear strength. Except for the group in which acorn tannin was used in spruce plywood, all groups met the requirements of EN 314-1 standard.

The reason for choosing the flask method in measuring formaldehyde emission was to compare the effects of the filling materials on formaldehyde emission. The use of the elm bark extract reduced the formaldehyde emission of pine plywood by $40 \%$. The use of $5 \%$ acorn tannin reduced the formaldehyde emission by $34 \%$ in pine plywood and $37 \%$ in spruce plywood. The other fillers reduced the formaldehyde emission in the range of $3 \%$ to $31 \%$.

The formaldehyde emission problem in the woodbased board sector is an issue that needs to be seriously addressed due to the increasing legal requirements that are developed in parallel with the increasing importance given to the environment and human health.

It was found that the extract obtained from the waste wood barks and hazelnut husk can be used as additives to substitute wheat flour in a glue mixture. It may be concluded from this study that elm bark extract may be used in a glue mixture as a formaldehyde scavenger in plywood panels.

\section{REFERENCES}

\section{LITERATURA}

1. Arbenz, A.; Avérous, L., 2015: Chemical modification of tannins to elaborate aromatic biobased macromolecular architectures. Green Chemistry, 17: 2626-2646. https:// doi.org/10.1039/C5GC00282F.

2. Aydın, İ.; Çolakoğlu, G.; Akbulut, T., 2001: Ağaç malzemenin yapıştırılmasında adhezyon teorisi. İstanbul Üniversitesi Orman Fakültesi Dergisi, 51: 91-100.

3. Aydin, I.; Colakoglu, G.; Colak, S.; Demirkir, C., 2006: Effects of moisture content on formaldehyde emission and mechanical properties of plywood. Building and Environment, 41 (10): 1311-1316. https://doi.org/10.1016/j.buildenv.2005.05.011.

4. Aydın, İ; Demirkır, C.; Çolak, S.; Çolakoğlu, G., 2010: Utilization of various bark flours as filler in plywood, III. National Black Sea Forestry Congress, Artvin-Turkey, 5: 1825-1833.

5. Aydin, I.; Demirkir, C.; Colak, S.; Colakoglu, G., 2017: Utilization of bark flours as additive in plywood manufac- 
turing. European Journal of Wood and Wood Products, 75 (1): 63-69. https://doi.org/10.1007/s00107-016-1096-0.

6. Bertaud, F.; Tapin-Lingua, S.; Pizzi, A.; Navarrete, P.; Petit-Conil, M., 2012: Development of green adhesives for fibreboard manufacturing, using tannins and lignin from pulp mill residues. Cellulose Chemistry and Technology, 46 (7-8): 449-455.

7. Böhm, M.; Salem, M. Z.; Srba, J., 2012: Formaldehyde emission monitoring from a variety of solid wood, plywood, blockboard and flooring products manufactured for building and furnishing materials. Journal of Hazardous Materials, 221; 68-79.

https://doi.org/10.1016/j.jhazmat.2012.04.013.

8. Chupin, L.; Motillon, C.; Charrier-El Bouhtoury, F.; Pizzi, A.; Charrier, B., 2013: Characterisation of maritime pine (Pinus pinaster) bark tannins extracted under different conditions by spectroscopic methods, FTIR and HPLC. Industrial Crops and Products, 49: 897-903. https://doi.org/10.1016/j.indcrop.2013.06.045.

9. Çolak, S., 2002: The Effects of Impregnation Procedure at Plywood on Technological Properties, Formaldehyde and acid emission of Plywood. Dissertation, Karadeniz Technical University.

10. Çolakoğlu, G., 1993: Effects of The Production Parameters on Formaldehyde Emission and Technical Properties of Plywood. Dissertation, Karadeniz Technical University.

11. Çöpür, Y.; Güler, C.; Akgül, M.; Taşçığlu, C., 2007: Some chemical properties of hazelnut husk and its suitability for particleboard production. Building and Environment, 42 (7): 2568-2572. https://doi.org/10.1016/j.buildenv.2006.07.011.

12. Dorner, F.; Berger, D.; Müller, U.; Brüggemann, O.; Panzer, U., 2012: Rapid determination of formaldehyde emission potentials of binders for the woodworking industry. European Journal of Wood and Wood Products, 70 (1-3): 299-306. https://doi.org/10.1007/s00107-011-0558-7.

13. Elbadawi, M.; Osman, Z.; Paridah, T.; Nasroun, T.; Kantiner, W., 2015: Mechanical and physical properties of particleboards made from Ailanthus wood and UF resin fortified by Acacias tannins blend. Journal of Materials and Environmental Sciences, 6 (4): 1016-1021.

14. Feng, S.; Cheng, S.; Yuan, Z.; Leitch, M.; Xu, C. C., 2013: Valorization of bark for chemicals and materials: A review. Renewable and Sustainable Energy Reviews, 26: 560-578. https://doi.org/10.1016/j.rser.2013.06.024.

15. Gangi, M.; Tabarsa, T.; Sepahvand, S.; Asghari, J., 2013: Reduction of formaldehyde emission from plywood. Journal of Adhesion Science and Technology, 27 (13): 14071417. https://doi.org/10.1080/01694243.2012.739016.

16. Moubarik, A.; Pizzi, A.; Charrier, F.; Allal, A.; Badia, M.; Mansouri, H. R.; Charrier, B., 2013: Mechanical characterization of industrial particleboard panels glued with cornstarch-mimosa tannin-urea formaldehyde resins. Journal of Adhesion Science and Technology, 27 (4): 423-429. https://doi.org/10.1080/01694243.2012.711739.

17. Nemli, G., 2002: Factors affecting the production of E1 type particleboard. Turkish Journal of Agriculture and Forestry, 26 (1): 31-36.

18. Nemli, G.; Çolakoğlu, G., 2005: Effects of mimosa bark usage on some properties of particleboard. Turkish Journal of Agriculture and Forestry, 29 (3): 227-230.

19. Ogunwusi, A. A., 2013: Potentials of industrial utilization of bark. Journal of Natural Sciences Research, 3: 106-115.

20. Ping, L.; Brosse, N.; Chrusciel, L.; Navarrete, P.; Pizzi, A., 2011: Extraction of condensed tannins from grape pomace for use as wood adhesives. Industrial Crops and Products, 33 (1): 253-257.

https://doi.org/10.1016/j.indcrop.2010.10.007.
21. Pirayesh, H.; Khanjanzadeh, H.; Salari, A., 2013: Effect of using walnut/almond shells on the physical, mechanical properties and formaldehyde emission of particleboard. Composites, Part B: Engineering, 45 (1): 858-863.

22. Pizzi, A., 1979: The chemistry and development of tannin/ urea-formaldehyde condensates for exterior wood adhesives. Journal of Applied Polymer Science, 23 (9): 2777 2792. https://doi.org/10.1002/app.1979.070230922.

23. Pizzi, A.; Valenezuela, J.; Westermeyer, C., 1994: Low formaldehyde emission, fast pressing, pine and pecan tannin adhesives for exterior particleboard. Holz als Rohund Werkstoff, 52 (5): 311.

24. Pizzi, A.; Mittal, K. L. (eds.), 2010: Wood adhesives. CRC Press, Leiden, Boston.

25. Ružiak, I.; Igaz, R.; Krišt’ák, L.; Réh, R.; Mitterpach, J.; Očkajová, A.; Kučerka, M., 2017: Influence of urea-formaldehyde adhesive modification with beech bark on chosen properties of plywood. BioResources, 12 (2): 3250-3264.

26. Salem, M. Z.; Böhm, M.; Srba, J.; Beránková, J., 2012: Evaluation of formaldehyde emission from different types of wood-based panels and flooring materials using different standard test methods. Building and Environment, 49: 86-96. https://doi.org/10.1016/j.buildenv.2011.09.011.

27. Salem, M. Z. M.; Böhm, M., 2013a: Understanding of formaldehyde emissions from solid wood: an overview. BioResources, 8 (3): 4775-4790.

28. Salem, M.; Böhm, M.; Srba, J., 2013b: Evaluation of mechanical properties and formaldehyde emission of plywood manufactured for construction applications. Drvna industrija, 64 (2): 87-93. https://doi.org/10.5552/drind.2013.1245.

29. Stefanowski, B. K., 2018: Improving Indoor Air Quality (IAQ) Through Novel Wood-based Panel Modifications. Doctoral dissertation, Bangor University.

30. Tan, H.; Çolakoğlu, G., 2010: The effect of using acorn flour as a filler on some mechanical and physical properties of Beech and Okume plywood boards, III. National Black Sea Forestry Congress, 5: 20-22.

31. Yazaki, Y.; Collins, P. J., 1994: Wood adhesives based on tannin extracts from barks of some pine and spruce species. Holz als Roh-und Werkstoff, 52 (5): 307.

32. Zhang, J.; Kang, H.; Gao, Q.; Li, J.; Pizzi, A.; Delmotte, L., 2014: Performances of larch (1 arix gmelini) tannin modified urea-formaldehyde (TUF) resin and plywood bonded by TUF resin. Journal of Applied Polymer Science, 131 (22). https://doi.org/10.1002/app.41064.

33. ***EN 314-1, 1993: Plywood - Bonding quality, Part 1: Test methods. European standard.

34. ***EN 717-3, 1996: Wood-Based panels - Determination of formaldehyde release, Part 3: Formaldehyde release by the flask method. European standard.

35. ***TAPPI T m-45, 1992: TAPPI Test Methods 19921993, TAPPI Press Atlanta, Georgia, U.S.

36. ***URL 1: http://dceg.cancer.gov/news-events/linkagenewsletter/2011-11/research-publicati- ons/formaldehyde (Accessed October 12, 2018).

\section{Corresponding address:}

\section{UGUR BILGIN}

Karadeniz Technical University

Faculty of Forestry

Department of Forest Industry Engineering

61080 Trabzon, TURKEY

e-mail: ugurbilgin@ktu.edu.tr 